\title{
The Effect of Organizational Culture on Firm Performance With Social Responsibility as Mediating Variable
}

\author{
Muliati Muliati ${ }^{1}$, Mohammad Iqbal $^{1} \&$ Arung Gihna Mayapada ${ }^{1}$ \\ ${ }^{1}$ Accounting Department, Faculty of Economics and Business, Universitas Tadulako, Palu, Indonesia \\ Correspondence: Arung Gihna Mayapada, Accounting Department, Faculty of Economics and Business, Universitas \\ Tadulako, Palu, Indonesia. Tel: 62-852-4052-8707. E-mail: arunggihna@gmail.com
}

Received: June 23, 2020

Accepted: August 18, 2020

Online Published: September 5, 2020

doi:10.5430/rwe.v11n5p279

URL: https://doi.org/10.5430/rwe.v11n5p279

\begin{abstract}
There is a lack of state-owned enterprises (SOEs) and regional-owned enterprises (ROEs) of Indonesia in reporting their social responsibility activities to the provincial governments. At the same time, corporate social responsibility is a mandatory obligation outlined in the Indonesia law. This study aims to analyze the mediating effect of social responsibility in relationship organizational culture and firm performance of SOEs and ROEs in Central Sulawesi Province, Indonesia. This study is survey research by distributing questionnaires to respondents who are SOEs and ROEs employees. The total sample is 245 respondents. The data are analyzed using path analysis. The result of this study shows that organizational culture does not affect firm performance partially. Another finding shows that SOEs and ROEs' organizational culture affects firm performance if the firm does and reports corporate social responsibility. These results mean that social responsibility plays a vital role in increasing firm performance besides focusing on improving organizational culture.
\end{abstract}

Keywords: firm performance, organizational culture, social responsibility, state/regional-owned enterprises

\section{Introduction}

Republic of Indonesia Law No. 40 of 2007 concerning Limited Liability Companies states that social responsibility is a mandatory obligation for companies. These obligations not only apply to private companies but also state-owned enterprises (SOEs) and regional-owned enterprises (ROEs). The regulation was even regulated earlier in SOE Ministerial Decree No. Kep-236/MBU/2003 concerning cooperation and environmental awareness programs. The practice of social responsibility by SOEs and ROEs is unusual to analyze because there are distinguishing factors with non-SOEs and ROEs companies given that SOEs and ROEs are owned by the government and generally managed through government regulations.

Researchers on organizational culture relations have been widely conducted in publicly owned companies. Meanwhile, this study will focus on companies whose shares are majority-owned by the government, namely SOEs and ROEs. SOEs and ROEs tend to have intense pressure in implementing CSR by the government due to being bound by regulations. Therefore, this study differs from the majority of previous studies that focused on private companies.

Researches about social responsibility in the public sector are not many done, besides public sector organizations, especially SOEs and ROEs, have a regulation like SOE Ministry Decree number KEP-236/MBU/2003 stating about $2 \%$ of profit for social responsibility activities. However, whether the funds have been used on target or only to abort obligations. It can be seen that the social responsibility activities of SOEs and ROEs are only oriented to charity shortly. CSR activities should be oriented towards empowering and strengthening production assets for the poor society to provide sustainable benefits. This study uses the organization culture variable in the research model.

Lako (2008) and Strandholm et al. (2018) explained that a business person, who wants his company is sustainable, must view CSR like primary needs internalized in the formulation of vision, mission, business strategy and policy, corporate culture values, and business actions. Excellent firm performance can be achieved with a humanistic approach to culture (Melo, 2012). Usman \& Amran (2015) stated that social responsibility to enhance corporate financial performance. Therefore, this study aims to know whether firm culture affects social responsibility and firm performance or not and whether social responsibility mediates the effect of firm culture on firm performance or not. 


\section{Literature Review}

Corporate social responsibility (CSR), according to Carroll (1999), is the company's basic rules governing companies to gain economic benefits by following applicable laws and supporting them morally, ethically, and socially. Social accounting, accounting for social responsibility, also known as corporate social responsibility. Gray et al. (1988) described the expansion of accounting reports to include information about products, employee interests, community activities, and environmental impacts. Mathews (1995) stated that the disclosure of social responsibility includes disclosure of information about the interaction of organizations with the environment and society, including community involvement, the natural environment, human resources, energy, and product safety.

According to Hackston \& Milne (1996), the disclosure of corporate social responsibility is the process of communicating the social and environmental impacts of the economic activities of the organization to the particular interest group and society as a whole. Gray et al. (1988) defined CSR disclosure as a process of providing information designed to carry out social accountability. The organization usually performs these actions, and they report such information in annual reports, special publications, or even socially-oriented ads. Companies that conduct CSR will be distinguished from the disclosure of social responsibility made following the company's actions (Luethge \& Guohong Han, 2012).

The Commission for European Communities stated that companies responsible socially do not solely comply with the obligations imposed on them under the rule of law but those that perform compliance beyond the rule of law and invest more in human capital, the environment, and the environment relationships with stakeholders (Szczanowicz \& Saniuk, 2016). According to Carroll (1979), social responsibility can be seen based on four dimensions, namely:

1. Economic responsibility is the responsibility of generating profits for a company.

2. Legal responsibility, which is the responsibility of fulfilling the economy in terms of applicable legal provisions.

3. Ethical responsibility, i.e., the company does something right and fair as a form of responsibility.

4. Discretionary responsibility is corporate responsibility in contributing to social life. This obligation is voluntary.

The Global Reporting Initiative (GRI) (2002) has developed a framework that distinguishes economic, social, and environmental performance. For GRI, the social dimension of sustainability that leads to CSR implementation is needed, including the community, employees, consumers, local communities, supply chains, and business associates.

\subsection{Organization Culture}

Organizational culture is a system that contains the primary and dominant values held by members in the organization, referred to as the organization's underlying philosophy, which distinguishes the organization from others (Robbins \& Judge, 2012). Melo (2012) showed that companies that combine a humanistic approach to culture would produce excellent performance because internal cultural values and beliefs will encourage them to build good relationships with stakeholders. According to Denison (1996), there are four main and integrative principles of the interrelationships between organizational culture and the effectiveness of corporate performance that include dimensions of organizational culture: adaptability, involvement, consistency, and mission.

The organizational culture associated with a firm performance by Kotter \& Heskett (1992) includes three ideas:

1. Integration of goals.

2. Influential culture helps to improve performance because it creates an extraordinary level in the employees.

3. Influential culture helps improve performance because it provides the necessary structures and controls without having to rely on rigid formalities that can suppress the growth of motivation and innovation.

Culture can only be a source of competitive advantage if it is valuable (adding value in some way), rarely (cultural attributes not the same as other companies), and can not be mimicked perfectly (De Luca et al., 2018; Sadri \& Lees, 2001). Therefore, an influential culture implies homogeneity and pervasiveness of cultural values.

\subsection{Firm Performance}

Firm performance is the firm's achievement in a period measured based on performance measurement standards. Firm performance can be measured by multiple perspectives, which are include both financial and non-financial perspectives. Kaplan \& Norton (1996) formulated a performance assessment derived from vision and strategy in a balanced way through four perspectives: financial, customer, internal business processes, and learning and growth. These four perspectives become an inseparable unity and are indicators of performance measurement. 
There are three stages of industrial development, namely; growth, maintain and harvest (Kaplan \& Norton, 1996). Each stage will require a different strategy. Based on a financial perspective, there are three aspects of a company's strategy:

1. Revenue growth and a combination of income from business organization.

2. Cost reduction and increased productivity.

3. Using assets optimally and investment strategies.

From the customer's perspective, firms need to create and present more value to consumers. More value occurs when benefits received by consumers are more significant than the value of the acquisition. Measurement of customer perspective can be done in two ways. Firstly, the core measurement group measures satisfaction, loyalty, linkage, consumer acquisition of the targeted market, and profitability obtained from the target market served. Secondly, the preposition of customer value, which is performance, triggers regarding what the company should serve to achieve high levels of satisfaction, loyalty, retention, and consumer acquisition.

From the perspective of internal business processes, the company focuses on three main business processes, namely: the innovation process, the moving process, and the post-sales process (Kaplan \& Norton, 1996). Managers and employees create products that guarantee customer satisfaction and shareholders' satisfaction.

The last perspective is a growth and learning perspective. Companies need to continue to pay attention to their employees, monitor employee welfare, and increase employee knowledge that will enhance employees' ability to participate in achieving results from three perspectives and company goals (Kaplan \& Norton, 1996).

\subsection{The Effect of Organizational Culture on Social Responsibility}

Russo \& Fouts (1997) argued that corporate social responsibility is characterized as a culture within organizations. The organizational culture perspective positively influences the corporate social responsibility (Halkos \& Skouloudis, 2017). Furthermore, Jones et al. (2007) highlighted that social performance through involvement with stakeholders is central to the organization's culture. The organizational culture divides into three dimensions of orientation: market, humanistic, and competitive (Galbreath, 2009; Maignan et al., 1999). Both of these orientations may present a set of characteristics that interact directly with the CSR (Galbreath, 2009).

Humanistic cultures consist of social values associated with a sense of involvement and collaboration between members of the organization, the sense that regardless of hierarchy, people contribute to decisions that affect their work and that this contribution is in tandem with organizational goals and business practices (Fey \& Denison, 2003; Galbreath, 2009; Kalyar et al., 2013). An influential organizational culture will support the achievement of organizational performance (Kalyar et al., 2013). Based on the above description, the hypothesis is proposed as follows:

H1: Organizational culture affects the implementation of social responsibility.

\subsection{The Effect of Social Responsibility on Firm Performance}

Corporate social responsibility (CSR) done by a company can affect company performance. This sentence is consistent with Vergalli \& Poddi (2009) findings that companies performing social responsibility will have long-term performance. Initially, the company incurs costs for the CSR but obtains higher sales and profits due to several causes, namely reputation effects and long-term cost reductions in response to demands for social responsibility.

Margolis \& Walsh (2003) stated that many studies had shown a positive relationship between CSR and financial performance. Stefan \& Paul (2008) also showed a positive relationship between environmental performance and financial performance. De Giovanni (2012) found that environmental management directly improves social and environmental performance, while environmental management has an indirect effect on economic performance.

The research of Valmohammadi (2014) provides empirical evidence between the practice of CSR and organizational performance in the Iranian context. The result of Iqbal \& Parwati (2013) proved that the disclosure of environmental information affects the company's value. Similarly, Muliati (2014) found that the disclosure of social responsibility that reflects the corporate social responsibility activities that have been done affects the company's environmental performance. Thus, organizations that implement CSR practices also report better organizational performance (Ridwan \& Mayapada, 2020). Based on the above description, the hypothesis is proposed as follows:

H2: Social responsibility affects firm performance. 


\subsection{The Effect of Organizational Culture on Firm Performance}

Denison et al. (2004) tested 34 companies representing 25 different industries. His research results show that two indices, "work organization" and "decision making," found significantly correlated with financial performance. Also, he found that cultural strength is a short-term performance prediction when performance is defined by broad indicators such as return on asset, return on investment, and return on sales.

Gordon \& DiTomaso (1992) found evidence in favor of Denison et al. (2004) that an influential culture predicts short-term corporate performance. The results are consistent with the results obtained by Chatman \& Jehn (1994), who found that companies in different industries developed different cultural patterns to meet their business demands. Lee \& Yu (2004) showed that organizational culture strength is related to organizational performance in some cases. Besides, the cultural elements that differentiate companies from each other are also related to performance. Based on the above description, the hypothesis is proposed as follows:

H3: Organizational culture affects firm performance.

\section{Method}

\subsection{Population and Sample}

This study's population is SOEs and ROEs employees in Center Sulawesi Province doing CSR internally and externally. The respondents are employees in the administration department in the center and main branch office in Palu City, the capital city of Center Sulawesi Province. Sampling is done by using the Slovin method so that the total sample is 245 respondents.

\subsection{Variables Description}

This study employs three variables i.e., Firm Performance (FP), Organizational Culture (OC), and Corporate Social Responsibility (CSR). Firm Performance (Y) is the achievement of the company in a period that is measured using the Balanced Scorecard approach, which consists of four perspectives: finance, customers, internal business, growth, and learning (Kaplan \& Norton, 1996). Organizational Culture (X1) is the primary and dominant values embraced by members of the organization, which serve as the organization's underlying philosophy, which differentiates the organization from others. Four indicators measure organizational culture: involvement, consistency, adaptability, and mission adopted by (Mobley et al., 2005). Corporate Social Responsibility (X2) is an activity which the company to fulfill all interests both to shareholder, employees, consumers, government, and environment where society resides. Four indicators measure the social responsibility of the research according to the Carroll (1999) model are economic, legal, ethical, and discretionary indicators.

\subsection{Data Analysis}

Research data obtained are tested their validity and reliability first, and next are analyzed using the Partial Least Square method. Measurement of all variables using the ordinal scale. Instruments used in this study using questionnaires, with answer options presented on Likert scale 5 points with choices: strongly disagree (1), disagree (2), hesitate (3), agree (4), and strongly agree (5). Interpreting the responses of respondents in the frequency of answers to the statements of each variable then shown in an interval scale as follows:

$$
\begin{gathered}
\text { Interval }=\frac{\text { Highest Score }- \text { Lowest Score }}{\text { Highest score }} \\
\text { Interval }=\frac{5-1}{5}=0.8
\end{gathered}
$$

Table 1. Basic interpretation of item score in research variables

\begin{tabular}{cc}
\hline Score Value & Interpretation \\
\hline $1.0-1.8$ & Not good / Very low \\
$>1.8-2.6$ & Less good / Low \\
$>2.6-3.4$ & Good enough / Low enough \\
$>3.4-4.2$ & Good / High \\
$>4.2-5.0$ & Very Good / Very High \\
\hline
\end{tabular}




\section{Results and Discussions}

\subsection{Results}

The structural model is evaluated by considering predictive relevance (Q2), which depends on the dependent variables' determination. Q2 has a value with a range of $0<\mathrm{Q} 2<1$, the closer to 1 means the model is getting better. The evaluation result of Goodness of Fit Model shows that Q2 $=1-(1-\mathrm{R} 12)(1-\mathrm{R} 22)$ is 0.75 which means that the model is appropriate, able to explain the phenomenon of company performance according to $75.4 \%$, while $24.6 \%$ explained by other variables that have not yet entered into this research model. The results of path analysis can be seen in the model in Figure 1.

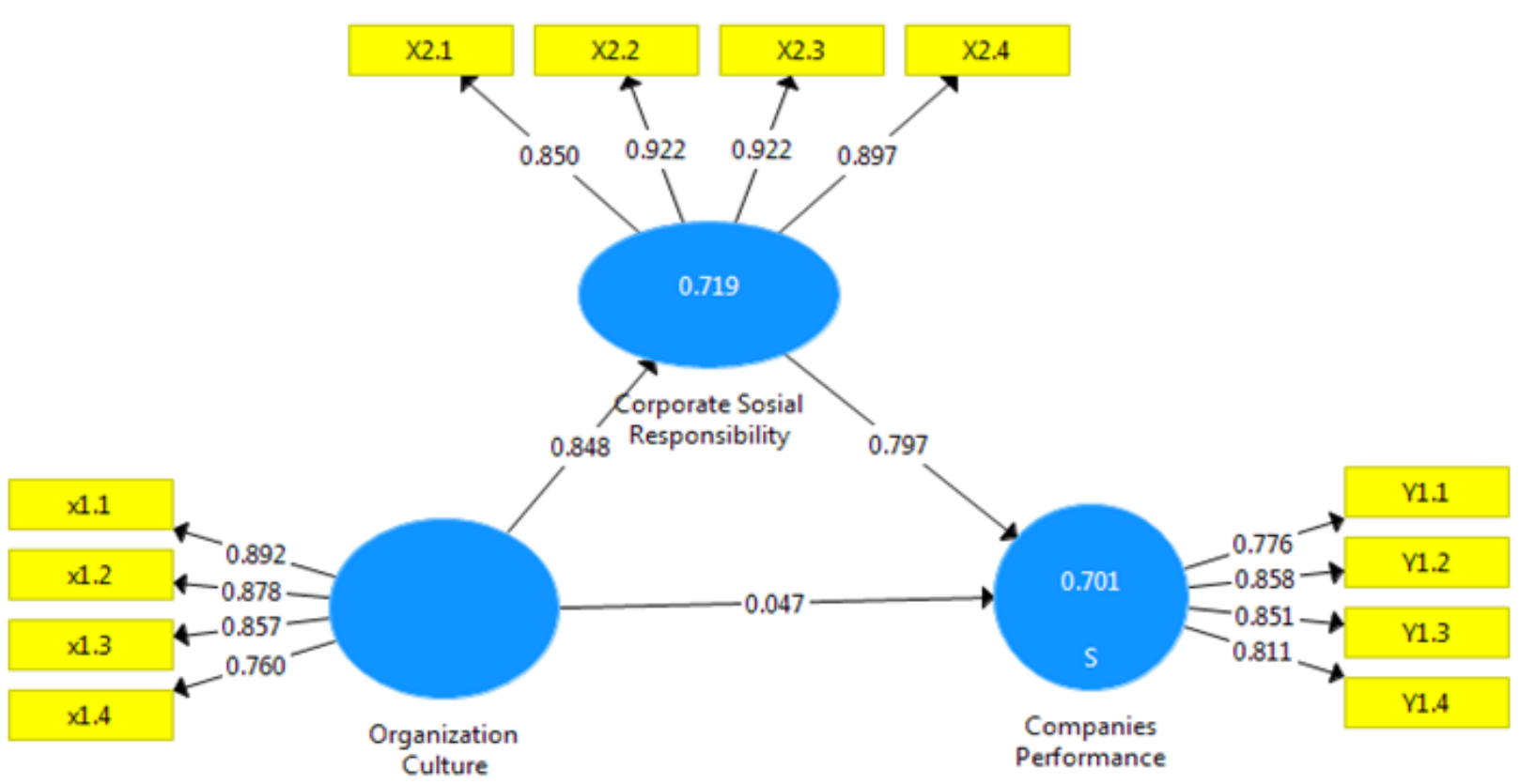

Figure 1. Model for corporate social responsibility in mediating organization culture to firm performance

Based on the output of the PLS model (Figure 1), it can be explained that the value of the outer loading indicator of the organizational culture variable (Organization Culture) is highest and that it is 0.892 indicator X1.1 = involvement. This result means that the organizational culture variable is more influential reflected by the engagement indicator. The variable of social responsibility is reflected by indicator X2.1 = legal responsibility and X2.2 = Ethical responsibility with an outer loading value of 0.922 . Which means that the social responsibility of SOEs and ROEs of Central Sulawesi Province is more strongly reflected on the legal responsibility and ethical responsibility. The firm performance variable is more strongly reflected by indicator Y1.2 = Customer Perspective, with the value of outer loading equal to 0,858 . This result shows that the performance of SOEs and ROEs is strongly reflected in the Customer Perspective.

Structural model testing and hypothesis testing are done by looking at the value of path coefficient estimation and $\mathrm{P}$-Value (t-statistic), which is significant at $\alpha=0,05$. The value of the path coefficient can be seen in Table 2 .

Table 2. The path coefficient of hypothesis testing

\begin{tabular}{lccc}
\hline \multicolumn{1}{c}{ Path Coefficient } & $\begin{array}{c}\text { Path } \\
\text { Coefficient }\end{array}$ & P Values & Decision \\
\hline Organization Culture -> Social Responsibility & 0.848 & 0.000 & Significant \\
Organization Culture -> Firm Performance & 0.047 & 0.449 & Non-significant \\
Social Responsibility -> Firm Performance & 0.797 & 0.000 & Significant \\
Organization Culture -> Social Responsibility -> Firm Performance & 0.676 & 0,000 & Significant \\
\hline
\end{tabular}


The above path model shows that a significant direct path of influence, i.e., the path of Organizational Culture with Social Responsibility, with a path value of 0.848 and p-value $0.00<0.05$, and the path of Corporate Social Responsibility with Firm Performance, the path value of 0.797 and p-value $0.00<0.05$. While the path is not significant, that is the path Organization Culture with Firm Performance, path value 0,047, and p-value 0,4498>0,05. While the coefficient of path indirect effect $=0.676$ and $p=0,000$, so it is said to be significant. These results suggest that organizational culture indirectly influences the improvement of firm performance through social responsibility.

\subsection{The Effect of Organizational Culture on Social Responsibility}

The result of this study indicates that the organizational culture of SOEs and ROEs of Central Sulawesi Province affects corporate social responsibility. This finding is supported by the mean value of organizational culture variables of 4.30 with very high criteria. With very high employee engagement, consistency, adaptability, and mission, it will support the implementation of social responsibility. This result is in line with Jones et al. (2007) that social performance through involvement with stakeholders is central to aspects of organizational culture. So companies that have a high cultural value will certainly involve employees in performing social responsibility, high consistency in applying habits or values, so that will affect the implementation of social responsibility. The result of this study indicates that the existence of corporate culture values oriented to corporate social and environmental responsibility.

\subsection{The Effect of Social Responsibility on Firm Performance}

Corporate social responsibility positively affects the firm performance of marked by the value of the path coefficient of 0.797 and the significance value of $0.00<0.05$. It can also be seen from respondents' mean value for social responsibility of 4.33 , a very high category which is in line with the mean value of company performance of 4.25 with a very high category. This finding can be interpreted to be that the better the implementation of social responsibility will be, the higher the firm performance. The outer model value of the highest indicator of legal responsibility and ethical responsibility is 0.922 in the social responsibility variable, indicating that in the implementation of the social responsibility of SOEs and ROEs of Central Sulawesi Province is more dominant in the implementation of legal responsibility and ethical responsibility.

Implementation of legal responsibility can be seen from the respondent's answer on items statement of legal responsibility of $48.39 \%$ stated strongly agree, and $36.40 \%$ agreed. This legal responsibility is in the form of making employment contracts with employees, providing salaries to employees above the applicable City Minimum Wage, no discrimination in compensation and promotion of office, paying attention to employees by completing equipment and safety equipment, complying with tax and other obligations to the government, and provide work accident insurance.

Implementation of ethical responsibility, which is a reflection of the implementation of the social responsibility of SOEs/ROEs is evidenced by respondents' answers to the items statement of $48.27 \%$ answered strongly agree, $40.15 \%$ answered agree. The ethical responsibility of SOEs/ROEs is to give the best service to the consumer, allowing the consumer to complain, give fair compensation, and always follow the regulation. The findings of this study are in line with the opinion of Vergalli \& Poddi (2009), which stated that companies performing social responsibility would have long-term performance (De Giovanni, 2012; Iqbal \& Parwati, 2013; Margolis \& Walsh, 2003; Muliati, 2014; Ridwan \& Mayapada, 2020; Stefan \& Paul, 2008; Valmohammadi, 2014).

\subsection{The Effect of Organizational Cultuer on Firm Performance Through Social Responsibility}

Organizational culture does not affect firm performance. It is seen from a path coefficient of 0.047 with P-Values $0,449>0,05$. This result indicates that organizational culture has no direct effect on firm performance; however, seen from the overall model, the organizational culture affects firm performance through corporate social responsibility.

The result of the research shows an indirect influence of organizational culture on firm performance through social responsibility equal to 0,676 with $\mathrm{p}$-value $=0,000$. This finding shows that the implementation of social responsibility based on a good organizational culture will support the achievement of firm performance.

Cultural values owned by SOEs/ROEs of Central Sulawesi Province, such as involving employees in any decision-making and activities of social responsibility, consistency, adaptability, and mission, will support the implementation of social responsibility in the firm performance. The average value of respondents' answers from the engagement indicator shows that the very high value of employee involvement in social responsibility implementation will undoubtedly lead to employee behaviors that will support the achievement of firm performance. The existence of consistent values in the implementation of social responsibility, the value of adaptability, and the mission of the company will improve firm performance. 
Firm performance measured from a financial perspective can be achieved with the fulfillment of economic responsibility, which is indicated by the achievement of profit that is a necessity for the survival of the company, and profit is something that must be obtained because it is the embodiment of social responsibilities to employees in providing appropriate compensation. From a customer perspective, this can be achieved with customer satisfaction, which is essential because it relates to the obligation to shareholders. Achieving customer satisfaction can make the consumer is loyal to the company so that interaction that can cause an increase in firm performance. Likewise, the firm performance from the perspective of learning is due to the increasing productivity of work, and the company always retains existing employees. It shows that in the SOEs/ROEs in Central Sulawesi Province able to encourage the increase of work productivity of employees by maintaining existing employees within a company. While from the internal business perspective caused the company to maintain with great care that employees do not make mistakes in working with guidance, and the company puts forward efficiency in the process of making products or services. If seen from these results, then the two mean values indicate the criteria very high, so it can be concluded that the company of SOEs/ROEs in Central Sulawesi Province prioritize efficiency by keeping the employees do not make mistakes. The results of this study are in line with the researches of Denison (1996), Gordon \& DiTomaso (1992), Lee \& Yu (2004), who found that an influential culture is a prediction of short-term firm performance.

\section{Conclusion}

In general, the study results provide evidence that the social responsibility of SOEs and ROEs of Central Sulawesi Province mediates the influence of organizational culture on firm performance. Implementation of social responsibility based on the values of organizational culture can affect the performance of SOEs and ROEs of Central Sulawesi Province. Reporting corporate social responsibility of SOEs in Central Sulawesi Province is generally included in the reporting of SOEs head office. While for ROE reported in the annual report. Implementation of corporate social responsibility of SOEs and ROEs of Central Sulawesi Province assessed based on indicators of economic responsibility, legal responsibility, ethical responsibility, and discretionary responsibility are included in a very high category.

Organizational culture can enhance corporate social responsibility. The culture of SOEs and ROEs of Central Sulawesi Province, based on the indicators of involvement, adaptability, consistency, and mission, are included in the first category that can influence the implementation of corporate social responsibility. Organizational culture has no direct effect on the company's performance, however the culture of SOEs indirectly to the firm performance through the social responsibility of SOEs and ROEs of Central Sulawesi Province.

This study has several limitations; First, this study only analyzed the sample of SOEs and ROEs operating in Central Sulawesi Province, so its generalization level is limited to Central Sulawesi Province. Further research might use samples from all over Indonesia so that the generalization level is broader applicable. Second, this study only captures the implementation of social responsibility, organizational culture, and firm performance during the study period, so it can not be compared over time. The next research might examine the tendency of implementing social responsibility, organizational culture, and firm performance over time.

\section{Acknowledgements}

Authors are indebted to the Directorate of Higher Learning, Ministry of Higher Learning, Research, and Technology, the Republic of Indonesia, which has provided funds for this research under Applied Product Research scheme $2017 / 2018$.

\section{References}

Carroll, A. B. (1979). A Three-Dimensional Conceptual Model of Corporate Performance. Academy of Management Review, 4(4), 497-505. https://doi.org/10.5465/amr.1979.4498296

Carroll, A. B. (1999). Corporate Social Responsibility: Evolution of a Definitional Construct. Business \& Society, 38(3), 268-295. https://doi.org/10.1177/000765039903800303

Chatman, J. A., \& Jehn, K. A. (1994). Assessing the Relationship between Industry Characteristics and Organizational Culture: How Different can You Be?. Academy of Management Journal, 37(3), 522-553. https://doi.org/10.5465/256699

De Giovanni, P. (2012). Do internal and external environmental management contribute to the triple bottom line?. International Journal of Operations \& Production Management, 32(3), 265-290. https://doi.org/10.1108/01443571211212574

De Luca, M. M. M., Parente, P. H. N., Silva, E. M. S., \& Sousa, R. R. (2018). The effect of creative corporate culture 
and intangibility on the performance of foreign firms traded on the NYSE. Innovation \& Management Review, 15(4), 356-372. https://doi.org/10.1108/INMR-07-2018-0049

Denison, D. R. (1996). What is the Difference Between Organizational Culture and Organizational Climate? A Native's Point of View on a Decade of Paradigm Wars. Academy of Management Review, 21(3), 619-654. https://doi.org/10.5465/amr.1996.9702100310

Denison, D. R., Haaland, S., \& Goelzer, P. (2004). Corporate Culture and Organizational Effectiveness. Organizational Dynamics, 33(1), 98-109. https://doi.org/10.1016/j.orgdyn.2003.11.008

Fey, C. F., \& Denison, D. R. (2003). Organizational Culture and Effectiveness: Can American Theory Be Applied in Russia?. Organization Science, 14(6), 686-706. https://doi.org/10.1287/orsc.14.6.686.24868

Galbreath, J. (2009). Drivers of Corporate Social Responsibility: The Role of Formal Strategic Planning and Firm Culture. British Journal of Management. https://doi.org/10.1111/j.1467-8551.2009.00633.X

Gordon, G. G., \& DiTomaso, N. (1992). PREDICTING CORPORATE PERFORMANCE FROM ORGANIZATIONAL CULTURE. Journal of Management Studies, 29(6), 783-798. https://doi.org/10.1111/j.1467-6486.1992.tb00689.x

Gray, R., Owen, D., \& Maunders, K. (1988). Corporate Social Reporting: Emerging Trends in Accountability and the Social Contract. Accounting, Auditing \& Accountability Journal, 1(1), 6-20. https://doi.org/10.1108/EUM0000000004617

Hackston, D., \& Milne, M. J. (1996). Some determinants of social and environmental disclosures in New Zealand companies. Accounting, Auditing \& Accountability Journal, 9(1), 77-108. https://doi.org/10.1108/09513579610109987

Halkos, G., \& Skouloudis, A. (2017). Revisiting the relationship between corporate social responsibility and national culture: A quantitative assessment. Management Decision, 55(3), 595-613. https://doi.org/10.1108/MD-12-2016-0868

Iqbal, M., \& Parwati, N. M. S. (2013). Effect of Environmental Accounting Implementation and Environmental Performance and Environmental Information Disclosure as Mediation on Company Value. International Journal of Business and Management Invention, 2(10), 55-67.

Jones, K., Krishnan, G. V., \& Malenderez, K. (2007). Do Models of Discretionary Accruals Detect Actual Cases of Fraudulent and Restated Earnings? An Empirical Evaluation. Working Papers, George Mason University \& New Mexico State University.

Kalyar, M. N., Rafi, N., \& Kalyar, A. N. (2013). Factors Affecting Corporate Social Responsibility: An Empirical Study: Factors Affecting Corporate Social Responsibility. Systems Research and Behavioral Science, 30(4), 495-505. https://doi.org/10.1002/sres.2134

Kaplan, R. S., \& Norton, D. P. (1996). The balanced scorecard: Translating strategy into action. Harvard Business School Press.

Kim Jean Lee, S., \& Yu, K. (2004). Corporate culture and organizational performance. Journal of Managerial Psychology, 19(4), 340-359. https://doi.org/10.1108/02683940410537927

Kotter, J. P., \& Heskett, J. L. (1992). Corporate culture and performance. Free Press, Maxwell Macmillan Canada, Maxwell Macmillan International.

Lako, A. (2008). Kewajiban CSR dan Reformasi Paradigma Bisnis dan Akuntansi. USAHAWAN, 6(XXXVII).

Luethge, D., \& Guohong Han, H. (2012). Assessing corporate social and financial performance in China. Social Responsibility Journal, 8(3), 389-403. https://doi.org/10.1108/17471111211247965

Maignan, I., Ferrell, O. C., \& Hult, G. T. M. (1999). Corporate Citizenship: Cultural Antecedents and Business Benefits. Journal of the Academy of Marketing Science, 27(4), 455-469. https://doi.org/10.1177/0092070399274005

Margolis, J. D., \& Walsh, J. P. (2003). Misery Loves Companies: Rethinking Social Initiatives by Business. Administrative Science Quarterly, 48(2), 268. https://doi.org/10.2307/3556659

Mathews, M. R. (1995). Social and environmental accounting: A practical demonstration of ethical concern?. Journal of Business Ethics, 14(8), 663-671. https://doi.org/10.1007/BF00871347 
Melo, T. (2012). Determinants of corporate social performance: The influence of organizational culture, management tenure and financial performance. Social Responsibility Journal, 8(1), 33-47. https://doi.org/10.1108/17471111211196557

Mobley, W. H., Wang, L., \& Fang, K. (2005). Organizational Culture: Measuring and Developing It in Your Organization. Harvard Business Review China, 3, 128-139.

Muliati, M. (2014). Corporate Social Disclosure as Mediating Variable on Effect of Financial Resources, Capability, and Characteristic of Corporate to Environmental Performance. International Journal of Scientific and Technology Research, 3(8).

Ridwan, R., \& Mayapada, A. G. (2020). Does sharia governance influence corporate social responsibility disclosure in Indonesia Islamic banks?. Journal of Sustainable Finance \& Investment, 1-20. https://doi.org/10.1080/20430795.2020.1749819

Robbins, S. P., \& Judge, T. (2012). Essentials of organizational behavior (11th ed.). Pearson Prentice Hall.

Russo, M. V., \& Fouts, P. A. (1997). A Resource-Based Perspective On Corporate Environmental Performance And Profitability. Academy of Management Journal, 40(3), 534-559. https://doi.org/10.5465/257052

Sadri, G., \& Lees, B. (2001). Developing corporate culture as a competitive advantage. Journal of Management Development, 20(10), 853-859. https://doi.org/10.1108/02621710110410851

Stefan, A., \& Paul, L. (2008). Does It Pay to Be Green? A Systematic Overview. Academy of Management Perspectives, 22(4), 45-62. https://doi.org/10.5465/amp.2008.35590353

Strandholm, K., Yoder, M., \& VanHemert, M. (2018). Acceptance of the Importance of CSR to Organizational Effectiveness: Impact of Cognitive Processes. Academy of Management Proceedings, 2018(1), 18660. https://doi.org/10.5465/AMBPP.2018.18660abstract

Szczanowicz, J., \& Saniuk, S. (2016). Evaluation and reporting of CSR in SME sector. Management, 20(1), 96-110. https://doi.org/10.1515/manment-2015-0027

Usman, A. B., \& Amran, N. A. B. (2015). Corporate social responsibility practice and corporate financial performance: Evidence from Nigeria companies. Social Responsibility Journal, 11(4), 749-763. https://doi.org/10.1108/SRJ-04-2014-0050

Valmohammadi, C. (2014). Impact of corporate social responsibility practices on organizational performance: An ISO 26000 perspective. Social Responsibility Journal, 10(3), 455-479. https://doi.org/10.1108/SRJ-02-2013-0021

Vergalli, S., \& Poddi, L. (2009). Does Corporate Social Responsibility Affect The Performance of Firms?. SSRN Electronic Journal. https://doi.org/10.2139/ssrn.1444333

\section{Copyrights}

Copyright for this article is retained by the author(s), with first publication rights granted to the journal.

This is an open-access article distributed under the terms and conditions of the Creative Commons Attribution license (http://creativecommons.org/licenses/by/4.0/). 